\title{
Winnie-the-Pooh jako obcy polskiej literatury
}

Artykuł ten poświęcony jest polskiej recepcji twórczości Alana Alexandra Milne'a dla dzieci. Choć książki te odniosły niebywały sukces na całym świecie, szczególnie Winnie-the-Pooh i The House at Pooh Corner, które zaliczane są powszechnie do klasyki literatury dziecięcej, a rola, jaką w Polsce - tuż po II wojnie światowej i w latach 50. - odegrał Kubuś Puchatek w przekładzie Ireny Tuwim, jest nie do przeceniania, czego świadectwa znaleźć można we wspomnieniach, relacjach czy dziełach postaci ważnych dla naszej literatury i kultury, to zdaje się, że sam autor i inne jego dzieła pozostają w Polsce zapomniane. Najpierw pokrótce przedstawimy więc genezę tych dzieł literackich, a następnie ich polską recepcję. Ważne będzie zbadanie, jakie czynniki wpłynęły na sukces Kubusia Puchatka w latach powojennych, ale i jak - niejako w sprzężeniu zwrotnym - sukces ten wpłynął na recepcję innych przekładów Winnie-the-Pooh (szczególnie Fredzi Phi-Phi Moniki Adamczyk-Garbowskiej) oraz innych dzieł A.A. Milne'a dla dzieci ${ }^{1}$.

${ }^{1}$ Kilka lat temu ukazał się już jeden tekst poświęcony recepcji Kubusia Puchatka, autorstwa Michała Rogoża (2012). Niniejszy artykuł nie jest oczywiście powtórzeniem myśli krakowskiego badacza, ale rozwinięciem niektórych wątków przez niego poruszonych i dodaniem innych ważnych kontekstów, o których on nie wspomina. 
Alan Alexander Milne był brytyjskim humorystą, dramatopisarzem, powieściopisarzem, poetą, a więc - jak on sam najpewniej by siebie określił - autorem literatury adresowanej do dorosłego czytelnika. I choć rzeczywiście pierwsze literackie sukcesy odniósł on dzięki artykułom publikowanym na łamach „Puncha” oraz dzięki dramatom, to w historii literatury zapisał się przede wszystkim dzięki twórczości dla dzieci.

Za pierwszy dziecięcy utwór A.A. Milne’a uznaje się często wiersz Vespers z 1923 roku. Lecz mimo że utwór ten z czasem stał się jednym z jego najpopularniejszych dzieł dla najmłodszych, tak naprawdę za pierwszy tekst napisany specjalnie z myślą o dzieciach trzeba uznać wiersz powstały pół roku później. Wtedy to, gdy pisarz z małżonką przebywali na zjeździe towarzystkim w Walii, do Alana zwróciła się Rose Fyleman z prośbą o stworzenie utworu do publikowanego przez nią czasopisma dla dzieci „The Merry-Go-Round”. Autor początkowo odmówił, lecz zaintrygowany propozycją, zaczął rozważać, jaki tekst mógłby napisać, gdyby się zgodził. W ten sposób powstał wiersz The Dormouse and the Doctor. Musiało być to dla Milne'a inspirujące zadanie, gdyż jeszcze w trakcie urlopu powstały kolejne wiersze, a kilka miesięcy później pracował już nad całym tomikiem. Do napisania opowiadań również przyczyniła się czyjaś prośba. Tym razem do A.A. Milne’a zwrócono się z czasopisma „The Evening News” - opowiadanie miało ukazać się w wigilijnym wydaniu gazety. Gdy pisarz szukał pomysłu na tekst, żona podpowiedziała mu, by spisał jedną z historii opowiadanych przed snem synowi, Christopherowi, i tak powstał pierwszy rozdział Winnie-the-Pooh. Zdaje się, że i to stało się bardzo inspirujące, ponieważ autor szybko przystąpił do pracy nad całą książką. Nie bez znaczenia okazały się też prośby bliskich - Alan w liście do brata ze stycznia 1926 roku wynotował najbliższe zobowiązania, a wśród nich - książkę o misiu (zob. Thwaite: 310).

Ostatecznie A.A. Milne opublikował cztery książki dla dzieci: dwa tomiki poezji oraz dwa zbiory opowiadań, które ukazywały się naprzemiennie - When We Were Very Young (1924), Winnie-the-Pooh (1926), Now We Are Six (1927) oraz The House at Pooh Corner (1928). Odniosły one niebywały sukces, co zaskoczyło twórcę, sam bowiem uznawał twórczość dla najmłodszych jedynie za poboczne i dodatkowe zajęcie. Twierdził: „Napisałem w sumie cztery »Książki 
dla Dzieci« [...] świadomy, że stworzyłem już w tym gatunku wszystko, na co było mnie stać, skończyłem pisanie książek dla dzieci. Chciałem uciec od nich [...]. Na próżno" (Milne, za: Thwaite: 378$)^{2}$.

Pisarz, przystępując do pracy nad pierwszymi utworami, miał sporo wątpliwości. Literatury dziecięcej nie traktowano wówczas poważnie, wydawało się, że każdy może napisać tekst dla najmłodszych. Sam Alan początkowo też tak to postrzegał, lecz z czasem dostrzegł, jak niełatwe jest napisanie dobrego utworu dziecięcego: „Wystarczająco trudne jest wyrażenie swoich myśli, gdy mamy do dyspozycji wszystkie wyrazy ze słownika. Gdy można użyć jedynie prostych słów, trudność okazuje się o wiele większa” (Milne, 1929: 132, tłum. A.Ch.).

Poważne traktowanie literatury dziecięcej, dobra technika, dbałość o słowo - wszystkie te elementy przyczyniły się do sukcesu wierszy oraz opowiadań. Krytycy chwalili je także za dobre wyczucie psychiki dziecka i jego prawdziwy portret; za przedstawienie natury ludzkiej tak, by było to zrozumiałe dla najmłodszych; za przekazanie uniwersalnych wartości, aktualnych przez całe życie. Według niektórych istotny jest też czas, w którym ukazały się te dzieła - w latach 20., w kilka lat po zakończeniu I wojny światowej. Traumatyczne wydarzenia wciąż były żywe wówczas w pamięci ludzi, potrzebowali więc oni doświadczyć, choćby w lekturze, dobrego i bezpiecznego świata. To tylko niektóre odczytania. Na przestrzeni lat, gdy popularność książek nie słabła, pojawiło się wiele prób wyjaśnienia powodów ich powodzenia.

2 Choć sam Milne wspomina o czterech książkach, może zastanawiać, czy aby na pewno jest autorem tylko tylu pozycji dla najmłodszych, ukazały się bowiem też: Once On a Time (1915/1917; w polskim przekładzie Jolanty Kozak jako Dawno, dawno temu), A Gallery of Children (1925) i The Prince Rabbit and the Princess Who Could Not Laugh (1966). Pierwsza z nich powstała na podstawie niezachowanej sztuki. Wydano ją w 1917 r. jako baśń dla dorosłych, lecz później zaczęto ją uznawać za tekst dla młodych czytelników. O książce tej sam autor mówił, że nie wie, do kogo tak naprawdę jest adresowana. Druga powstała na zamówienie amerykańskiego wydawcy. To zbiór dwunastu opowiadań, napisanych do przygotowanych wcześniej ilustracji. Milne nie wspomina nigdzie o tym zbiorze najpewniej dlatego, iż złościło go, że oddał wszystkie prawa oficynie, a pozycja sygnowana nazwiskiem znanego pisarza dobrze się sprzedawała. Trzecia ukazała się już po śmierci autora, najpewniej więc jego żona opublikowała teksty, które zachowały się w archiwach. Co ciekawe, książka ta została zupełnie pominięta przez badaczy twórczości Alana Alexandra, nikt nie podjął się zbadania choćby tego, dlaczego teksty te nie ujrzały światła dziennego za życia twórcy. Niejasny pozostaje również stosunek autora do jego sztuk dla dzieci: Make-Believe (1918) i Toad of Toad Hall (1929; adaptacja The Wind in the Willows Kenetha Grahame'a). 
Entuzjastyczna reakcja czytelników zaskoczyła autora i wydawców. Nakłady wszystkich dzieł, publikowanych równocześnie w Anglii i w USA, rozchodziły się w bardzo szybkim tempie (czasami jeszcze w dniu wydania). Wokół książek rozwinął się też przemysł „zabawkarski”. Na fali popularności książek wydawcy przygotowywali kolejne publikacje, produkowano też coraz więcej gadżetów związanych z Pooh i jego przyjaciółmi. Przygotowywano audycje radiowe, ukazało się kilka zbiorów z kompozycjami muzycznymi do wierszy Milne’a. Z czasem nagrywno również płyty - na niektórych z nich pewne fragmenty czytał sam pisarz, na innych śpiewał jego syn Christopher.

Książki dla dzieci A.A. Milne’a szybko zaczęto tłumaczyć na inne języki - już w latach 20. i 30. ukazały się pierwsze obcojęzyczne wersje wierszy oraz opowieści. Zdaje się jednak, że mimo dużego sukcesu, jaki w Wielkiej Brytanii oraz w USA odniosły poezje, w innych państwach większym zainteresowaniem cieszyły się opowiadania o Pooh i jego przyjaciołach ${ }^{3}$. Dzieła angielskiego pisarza zostały dotychczas przełożone na kilkadziesiąt języków, w tym nawet na łaciński i esperanto. Niezwykle ciekawy jest przypadek łacińskiej wersji pierwszej części przygód Pooh, czyli Winnie ille Pu z 1960 roku. Tłumaczowi, Alexandrowi Lenardowi, niełatwo było przekonać wydawców do publikacji - najpewniej spodziewali się, że po tę pozycję sięgnie tylko wąskie grono latynistów - tekst jednak odniósł niebywały sukces, przede wszystkim w USA, gdzie uplasował się na liście najlepiej sprzedających się książek obcojęzycznych. W 1980 roku, gdy książka Winnie ille Pu nadal cieszyła się zainteresowaniem, ukazał się łaciński przekład drugiej części, dokonany przez Briana Staplesa, czyli Domus Anguli Puensis.

Historię polskich przekładów tekstów A.A. Milne’a dla dzieci również otwierają opowiadania. Winnie-the-Pooh doczekało się czterech tłumaczeń, The House at Pooh Corner zaś dwóch:

3 Tori Haring-Smith ustaliła, że już w 1928 r. ukazała się niemiecka wersja Winnie-the-Pooh, a później światło dzienne ujrzały wersje duńska (1930), fińska (1934), holenderska (1936) i czeska (1938), podczas gdy w tym samym czasie When We Were Very Young ukazało się tylko w Holandii (1936). Można przypuszczać, że w latach 30. prace Milne’a przetłumaczono także na inne języki, jednak badaczce nie udało się do nich z różnych powodów dotrzeć. Odnotowuje ona na przykład, że polskie przekłady Tuwim pochodzą odpowiednio z 1946 i 1954 r., tymczasem obie części zostały wydane już w 1938 r. (zob. Haring-Smith: 67-68, 81-84, 91, 96-97). 


\begin{tabular}{|c|c|}
\hline Winnie-the-Pooh (1926) & The House at Pooh Corner (1928) \\
\hline $\begin{array}{c}\text { Kubuś Puchatek (1938), } \\
\text { przeł. Irena Tuwim* }\end{array}$ & $\begin{array}{c}\text { Chatka Puchatka (1938), } \\
\text { przeł. Irena Tuwim }\end{array}$ \\
\hline $\begin{array}{c}\text { Miś Puh-Niedźwiedzki (1943), } \\
\text { przeł. Maria Grażyna Ławrukianiec* }\end{array}$ & - \\
\hline $\begin{array}{c}\text { Fredzia Phi-Phi (1986), } \\
\text { przeł. Monika Adamczyk }\end{array}$ & $\begin{array}{c}\text { Zakatek Fredzi Phi-Phi (1990), } \\
\text { przeł. Monika Adamczyk-Garbowska }\end{array}$ \\
\hline $\begin{array}{c}\text { O Kubusiu Puchatku (1993), } \\
\text { przeł. Agnieszka Traut }\end{array}$ & - \\
\hline $\begin{array}{c}\text { Kubuś Puchatek (1994), } \\
\text { przeł. Bohdan Drozdowski }\end{array}$ & - \\
\hline
\end{tabular}

${ }^{*}$ Niektórzy badacze podają jako datę wydania rok 1937, jednak na podstawie biografii Ireny Tuwim (według ustaleń biografki w 1937 r. dopiero zaproponowano tłumaczce podjęcie się tego zadania; zob. Augustyniak: 179), a także na podstawie bibliografii prac Tuwim opublikowanej na stronie Fundacji im. Juliana Tuwim i Ireny Tuwim (zob. Bibliografia...) przyjmuję jako właściwy rok 1938. ${ }^{*}$ Przekład ten ukazał się na Węgrzech (por. Rogoż: 72). Publikacja obecnie jest nieosiągalna tak w Polsce, jak i za granicą. Do fragmentu tłumaczenia udało się dotrzeć Krzysztofowi Woźniakowskiemu, on też więcej pisze na ten temat (81-82).

Pierwszy zbiór doczekał się w Polsce tłumaczenia także na język regionalny - Miedzwiôdk Püfôtk z 2015 roku to przekład Bożeny Szymańskiej-Ugowskiej na język kaszubski - oraz dwie gwary - Misiu Szpeniolek z 2019 roku to tłumaczenie Juliusza Kuba na gwarę wielkopolską, a Niedźwiodek Puch z tego samego roku to tłumaczenie Grzegorza Kulika na gwarę śląską.

Zbigniew Herbert w 1956 roku, w kilka miesięcy po śmierci A.A. Milne’a, zastanawiał się nad fenomenem opowieści o Pooh:

Gdyby istniała socjologia literatury, musiałaby wyttumaczyć ogromną popularność Kubusia Puchatka na całym świecie. Niewątpliwe walory literackie tej książi nie powinny przesłonić faktu, że zagadnienie rozgrywa się właściwie poza sferą przeżyć estetycznych.

To prawda, niewiele jest dzieł, które równie trafnie oddają mentalność dzieci, ich procesy myślowe i emocjonalne. [...] „Charaktery” tej książki są pełne wyrazistości [...]. Dialog jest świetny, błyszczy humorem i nonsensem, akcja - pasjonująca, [...] ale to wszystko nie tłumaczy jeszcze ogromnego powodzenia tej książki, zwłaszcza u dorosłych.

(Herbert, 1956: 203)

Jak wspominaliśmy, prób wyjaśnienia tej poczytności na świecie było wiele. Do listy argumentów można dopisać zawartą w książkach filozofię, fakt, 
że wartości w nich przedstawione są aktualne przez całe życie. Źródła sukcesu można upatrywać też w bohaterach, którzy są alegoriami ludzkich postaw. Jeszcze inaczej ustosunkował się do tego A.R. Melrose:

Kubuś nie jest wszak misiem uniwersalnym. Poza japońskim i hebrajskim, wszystkie języki, na które książka została przetłumaczona, wywodzą się z chrześcijańskiego kręgu kulturowego [...] Kubuś Puchatek nie zdołał natomiast wniknąć w świat islamu i hinduizmu. [...]

Z drugiej strony wydaje się, że kraje, w których Kubuś Puchatek zrobił karierę, bardziej łączy względnie wysoki rozwój ekonomiczny niż religia. Dzięki temu, że umieralność dzieci jest tutaj znikoma, mogła rozwinąć się idea dzieciństwa jako odrębnego, wyraźnie określonego etapu życia, okresu beztroski i szczęścia [...].

(Melrose: 24-25)

Większość interpretatorów podąża jednak tropem arkadyjskim. Świat Pooh to świat bezpieczny. Tutaj zagrożenia okazują się nie tak groźne, problemy łatwe do rozwiązania, można liczyć na wsparcie innych (zob. Carpenter; Lurie, za: Thwaite: 321; Wullschläger).

W Polsce na znaczenie postaci stworzonych przez angielskiego pisarza zwracał uwagę Kazimierz Wyka. W 1948 roku pisał:

Podejrzewam, a rad bym usłyszeć, czy potwierdzą to fachowcy, podejrzewam zatem jako dorosły czytelnik, że są to [Kubuś Puchatek i Chatka Puchatka - dop. A.Ch.] arcydzieła swojego gatunku, a arcydzieła czy arcydziełka nie rodzą się nagminnie, lecz tylko niekiedy trafiają. I mają tę właściwość, że nabyte z nich prawdy psychologiczne i sformułowania dają się zastosować w wielu okolicznościach życia. Bo gdyby tak nie było, czyżby pewien dobrze mi znany pisarz nazywał od lat wszystkie swoje posiłki małym „Conieco”? Jak Puchatek. Czyżby inny pocieszał się stale, jak Kłapouchy: pada śnieg, bierze mróz, „jednakże nie mieliśmy ostatnio trzęsienia ziemi”. [...]

Tymczasem dobrotliwa znajomość człowieka, sztuka jasnego spojrzenia nawet na jego wady, to fundament dobrej prozy dla niedorosłych. Wartości takie posiadała zawsze w wysokim stopniu powieść angielska i dlatego Puchatek, Kłapouchy, Prosiaczek, Królik i Maleństwo tak po ludzku są ciepli, nawet kiedy bywają całkiem głupkowaci. Bo nad ich kolebką pochyla się sam Dickens, pochyla się aż do poszczególnych sytuacji.

(Wyka: 506-508) 
Następnie Wyka zestawił sceny, w których przyjaciele starają się wydostać Kłapouchego z wody (po tym, jak został on do niej „wbryknięty” przez Tygryska), z fragmentami Klubu Pickwicka Charlesa Dickensa, w których podobnie postępują towarzysze tytułowego bohatera, gdy podczas jazdy na łyżwach pod Pickwickiem załamuje się lód, a on wpada do wody.

W tonie arkadyjskim zaś wypowiadał się Herbert:

[...] przy samym końcu książki mały nieboskłon pęka. Dzieje się to wtedy, gdy Krzyś zwierza się Kubusiowi, w słowach pełnych delikatnych uczuć i poezji, że wkrótce idzie do szkoły. W świecie sielanki jednak nic się nie kończy i nikt nie umiera. Jest przecież Zaczarowane Miejsce Spotkań, gdzie rośnie „cicha, zielona trawa, gęsta i jedwabista".

Tu także spotykają się poeci arkadyjscy.

(Hebret, 1956: 204)

Herbert podkreślał, że w Polsce czytało się dzieło A.A. Milne’a jako sielankę. Zauważył: „,[m]echanizm tego świata nastawiony jest tylko na pomyślność i teraz łatwo zrozumieć, dlaczego książka ta tak popularna była w czasie, gdy mechanizm świata działał odwrotnie" (Herbert, 1956: 203). Opowiadania Milne'a, opublikowane w Polsce zaledwie rok przed wybuchem II wojny światowej, odniosły sukces właśnie wtedy, „gdy mechanizm świata zadziałał odwrotnie", czyli w czasie okupacji i po zakończeniu wojny. Wiąże się to więc poniekąd $\mathrm{z}$ angielską recepcją - w Wielkiej Brytanii opowieści o Pooh również stanowiły swoistą „odskocznię” dla tych, którzy doświadczyli okropieństw I wojny światowej.

Kubuś Puchatek był taką właśnie „odskocznią” dla samego Herberta. Andrzej Franaszek stwierdza, że w latach 50. w Polsce zainteresowanie książkami A.A. Milne’a nie słabło - „znów istniały liczne pozaliterackie powody, by rozczytywać się w sielankach, Herbert studiował więc Milne’a na zmianę z Biblią i pisał do swej kochanki, że Puchatek to najlepszy "plaster na wszystkie odciski«" (Franaszek: 608). W tym samym miejscu notuje również, że Herbert niejednokrotnie w listach pisał o sobie „Puchatek”, a niektórzy mówili o nim „Kłapouszek”. Pisarz pracował też nad sceniczną adaptacją Kubusia Puchatka (na potrzeby gdańskiego Teatru Lalek), choć - jak sam przyznawał - nie musiał wkładać w to wiele wysiłku - usunął jedynie opisy, pozostawiając dialogi. W jednym z listów pisał: „[...] wydźwięku oczywiście nie dorobię, bo jaki, że 
Osioł wstępuje na koniec do ZMP, a Kubuś wygłasza samokrytykę. He, he" (Herbert, za: Franaszek: 609). Ślad zainteresowania polskiego twórcy książkami Alana Alexandra można też dostrzec w jednej z próz poetyckich opublikowanych w 1957 roku:

Niedźwiedzie dzielą się na brunatne i białe oraz łapy, głowę i tułów. Mordy mają dobre, a oczka małe. One lubią bardzo łakomstwo. [...] Jak mają mało miodu, to łapią się rękami za głowy i są takie smutne, takie smutne, że nie wiem. Dzieci, które kochają Kubusia Puchatka, dałyby im wszystko, ale po lesie chodzi myśliwy i celuje z fuzji między te dwa małe oczka.

(Herbert, 1957: 136)

Znacznie później, bo w 1996 roku, po śmierci Chrisophera, syna Milne’a, który stał się dla ojca pierwowzorem postaci literackiej, powstała proza poetycka Czesława Miłosza Krzyśs. Poeta nawiązał w niej do zakończenia The House at Pooh Corner, w którym to Christopher odchodził z lasu. W tekście polskiego pisarza chłopiec tam wrócił. Jak relacjonuje miś:

[...] Sowa Przemądrzała mówi, że zaraz za naszym ogrodem zaczyna się Czas, a to jest taka studnia strasznie głęboka, w którą kiedy tylko ktoś wpadnie, leci i leci w dół, aż nie wiadomo, co się z nim potem dzieje. Martwiłem się trochę o Krzysia, żeby tam nie wpadł, ale wrócił i wtedy go zapytałem o tę studnię. „Puchatku - powiedział - byłem w niej i spadałem, i zmieniałem się spadając, nogi zrobiły mi się długie, byłem duży, nosiłem spodnie do ziemi i broda mi urosła, potem posiwiałem, zgarbiłem się, chodziłem o lasce i wreszcie umarłem. Pewnie to wszystko mi się tylko śniło, bo było jakieś nieprawdziwe".

(Miłosz: 226)

Biografista Herberta, mówiąc dalej o latach 50., przytacza również słowa Zdzisława Najdera, które potwierdzają, że niejedna osoba sięgała wówczas po przygoday Puchatka: „Całe to nasze »niezorganizowane«, niepartyjne, niemarksistowskie środowisko czy kręgi uniwersyteckie - wszyscy mówili Kubusiem Puchatkiem” (Najder, za: Franaszek: 608). Julia Hartiwg w wywiadzie wspomina zaś, iż pamięta, że Czesław Miłosz „przerzucał” i droczył się fragmentami Kubusia Puchatka w rozmowach z Jerzym Andrzejewskim czy z Jerzym i Anną Turowiczami. Poetka wspomina też, że sama w dzieciństwie z chęcią czytała przygody misia, a egzemplarz książki z autografem Tuwim (z datą 14 kwietnia 1950 r.) zachowała do dziś. Kubuś Puchatek był też żywy w pamięci Bohdana 
Butenki, który przyznawał, że powiedzenia z tej książki przypominają mu dzieciństwo (zob. Co czytali...: 31, 114, 105) .

Wieści o tym powodzeniu docierały do samej tłumaczki, która w czasie wojny przebywała na emigracji: „I nagle pod koniec wojny i tuż po niej zaczęły do mnie napływać wiadomości o puchatkowej karierze, o tym, że książka podobała się, że zyskała w naszym kraju prawo obywatelstwa, że puchatkowe powiedzonka weszły w codzienny język" (Tuwim, za: Augustyniak: 182). Znajomi w Anglii mówili o niej The Pooh Lady, w Polsce z czasem nazywano ją „matką chrzestną Puchatka” czy wręcz „matką Puchatka”. Po powrocie do kraju w 1947 roku mogła sama się przekonać, jak bardzo Polacy pokochali oba zbiory opowieści. Jak relacjonuje Augustyniak, w powojennej Polsce powstawały sklepy, kluby czy kawiarnie o nazwach zaczerpniętych z tych książek. W 1954 roku czytelnicy „Expressu Wieczornego” na patrona jednej z warszawskich ulic wybrali właśnie Puchatka. Z czasem zaczęto przygotowywać adaptacje radiowe i teatralne, wydawano płyty długogrające z Kubusiem Puchatkiem oraz Chatka Puchatka, a w latach 80. - ze słynnymi mruczankami misia (muzykę do nich napisał Edward Pałłasz). W 1957 roku Prezes Rady Ministrów przyznał Tuwim nagrodę artystyczną za przekłady książek dla dzieci, zaś w 1981 otrzymała ona nagrodę polskiego PEN Clubu dla tłumaczy za całokształt pracy przekładowej ze szczególnym uwzględnieniem przekładów z literatury angielskiej.

Sukces ten musiał cieszyć Tuwim, tym bardziej że początkowo wcale nie była ona chętna podjąć się tłumaczenia Winnie-the-Pooh. Gdy dostała taką propozycję z wydawnictwa w 1937 roku, odmówiła. Uznała bowiem, że niemożliwe jest przełożenie tego tekstu z uwagi na humor - tak różny od tego, jaki znają polscy czytelnicy. Możliwe także, iż tłumaczka nie była jeszcze pewna swoich kompetencji, dotychczas przełożyła tylko dwa teksty: dramat Augusta Strindberga (1930; wspólnie ze Stefanem Napierskim) i autobiografię austriackiej arystokratki Hermynii zur Mühlen (1931). Ponadto nie znała jeszcze tak dobrze języka angielskiego (tym też można wyjaśnić niektóre błędy w Kubusiu Puchatku oraz Chatce Puchatka), lepiej opanowała go dopiero na emigracji. Mimo tego właśnie w tamtym czasie zaczęła zajmować się przekładem,

${ }^{4} \mathrm{O}$ opowiadanicha tych wspomina także Janusz Gajos, choć nie o własnym doświadczeniu lekturowym, ale jego córki, mówi więc z pewnością o późniejszym okresie niż lata 50. (zob. Co czytali...: 114-115). 
szczególnie książek dla dzieci. Spolszczyła wówczas baśnie braci Grimm, bajki Walta Disneya i pierwszą książkę Pameli L. Travels o Mary Poppins ${ }^{5}$. Do pracy z tekstami A.A. Milne’a nakłoniła ją rodzina: „Na próbę przetłumaczyłam pierwszy rozdział i - rozsmakowałam się w tym. Wyczułam, że książki tej nie można tłumaczyć dosłownie, dlatego też zaczęłam dokonywać swego rodzaju adaptacji - oddając treść i sens oryginału, ale zawsze były to "wariacje na temat "” (Tuwim, za: Augustyniak: 179-180) ${ }^{6}$. Dokładniejszy wyraz swoich strategii translatorskich Tuwim dała w jednym z artykułów:

Tłumacz powinien ustawicznie sprawdzać samego siebie, nieraz zmieniać się nawet w autora, aby książkę przystosować do zasobu wiedzy, kręgu pojęć, poczucia realiów i języka u dzieci. [...] Aby tłumacz mógł dać utwory językowe najwyższej klasy konieczna jest znaczna swoboda we wszystkich przekładach [...].

(Tuwim: 10 [podkr. oryg.])

To właśnie wokół tych „wariacji na temat” i „znacznej swobody” toczyła się niezwykła dyskusja, gdy po blisko 50 latach od wydania Kubusia Puchatka i Chatki Puchatka ukazał się nowy przekład pierwszej z książek dokonany przez Monikę Adamczyk-Garbowską, czyli Fredzia Phi-Phi. Dyskusja niezwykła, ponieważ przede wszystkim emocjonalna, nie merytoryczna. Przekład Tuwim przez dziesięciolecia wrósł w kulturę polską, został uznany za znakomity, wrósł też w sam język, a czytelnicy szczerze pokochali Puchatka i jego przyjaciół, z miejsca zaś znienawidzili Fredzię (zob. Kozak: 31-39, 172-179; Woźniak, 2012, Gralewicz-Wolny: 227-240; Staniuk: 85-95). Najwięcej kontrowersji

\footnotetext{
5 W 1937 r. ukazał się Ztoty kluczyk, czyli niezwykte przygody Buratina (w oryginale: Zolotoj klûčik, ili Priklûčeniâ Buratino) Aleksieja Tołstoja. Choć przekłady podpisywane są nazwiskiem Juliana Tuwima, Irena po jego śmierci wyznała, że to ona przełożył tekst, ponieważ jej brat przyjął zlecenie, lecz nie znalazł czasu, by je zrealizować. Możliwe, iż właśnie dzięki temu zajęła się tłumaczeniem literatury dziecięcej.

${ }^{6}$ To tłumaczenie „na próbę” przypomina początki samego Alana Alexandra i jego poezji dla dzieci. Podobieństwo między tłumaczką a autorem można dostrzec w jeszcze jednej kwestii - Tuwim przełożyła prawie 60 tekstów (według ustaleń Januszewskiego 55 książek, należy jednak jego listę uzupełnić o dwie inne pozycje: wspomniany już wyżej dramat Strindberga, Eryk XIV, oraz książkę Pokój nie zna granic z 1953 r., tłumaczoną wspólnie z Ireną Krzywicka), jednak to przygody Puchatka pozostają jej najbardziej znanym dziełami, tak jak oryginalne teksty „królowały” nad innymi pracami Milne’a.
} 
budziło imię tytułowego bohatera. Do najbardziej skrajnych głosów należy zaliczyć wypowiedź Stanisława Lema, który stwierdził:

Bardzo rzadko zdarza się, aby tłumaczenie było lepsze niż oryginał. Znam jeszcze jeden [obok tłumaczeń tekstów Stefana Grabińskiego na niemiecki - dop. A.Ch.] taki przypadek. Kubuś Puchatek Ireny Tuwim jest to książka genialna. Natomiast tę panią, która zrobiła z Puchatka jakąś Fredzię Phi-Phi, to ja bym tępym nożem zamordował za to, co ona zrobiła z tej książki. [...] Ten pełen niezwykłego wdzięku tekst został po prostu wykastrowany. Natomiast Irena Tuwim dokonała tego, co jest takie rzadkie. Dokonała genialnej transformacji w język polski.

(Lem: 14)

W złośliwym wręcz tonie utrzymana jest wypowiedź Andrzeja Nowaka, który po wydaniu kontynuacji, Zakątka Fredzi Phi-Phi, na łamach czasopisma zwracał się do tłumaczki:

Na pohybel wrednemu Puchatkowi! Bo, jeśli już nawet przyjąć wersję Winnipegu, [...] pozostaje jeszcze drugi człon tej nazwy. A może by tak „Peggy” czyli „Gośka”? Choć nie, mam lepszy pomysł. Hejże za ciosem! [...] nazwa „Winnipeg” [...] brzmienie swe zawdzięcza słowom „win”- „szlamisty” i „nipee” - „woda”. Może by zatem - w kolejnych wydaniach - zrezygnować jednak z Fredzi i nazwać misia, powiedzmy, Mętniaczkiem-Jezioraczkiem lub Chlaptusiem-Przymułkiem? Gra chyba warta świeczki. Jak wierność, to wierność!

(Nowak: 12$)^{7}$

Pojawiały się wypowiedzi biorące w obronę nowe przekłady - na przykład tekst Jerzego Jarniewicza opublikowany w 1987 roku na łamach „Odgłosów” (Jarniewicz) - lecz ginęły one raczej w słowach krytyki. Bardzo prawdopodobne jest, iż po stronie Adamczyk-Garbowskiej stanąłby Robert Stiller, który w 1973 roku na marginesie rozważań o polskich przekładach Alice’s Adventures in Wonderland Lewisa Carrolla pochylił się też nad pracami Milne’a. Odróżnił on zdecydowanie adekwatne tłumaczenie od przyswojenia. Zaznaczył, że

\footnotetext{
7 Słowa o Winnipeg odnoszą się do wyjaśnienia Adamczyk-Garbowskiej, której zdaniem Winnie to zdrobnienie od imienia Winifreda (stąd też jej propozycja: Fredzia). Owszem, jest to prawda, jednak imię londyńskiej niedźwiedzicy, od której wziął swoje imię Pooh, pochodzi od miasta Winnipeg, należy więc przyznać rację krytykowi. Jeszcze inne krytyczne wypowiedzi przytacza Jolanta Kozak (zob. Kozak: 35-38).
} 
[...] wersja Ireny Tuwim, przy całej swej zręczności i wdzięku, przy dość znacznej wierności wielu partii prozaicznych, jest jednak raczej infantylizacją niż przekładem artystycznym utworu o dzieciach i również (albo przede wszystkim) dla dzieci, lecz ani trochę nie infantylnego. [...] akceptacja znakomitego w swym zakresie Kubusia Puchatka nie oznacza pogodzenia się ze sprzecznością np. między

adekwatnym polskim Winnie-the-Pooh a polskim Winnie-the-Pooh dla dzieci. Bo dzieci jednak zasługują nie na to, co infantylne, ale co najlepsze.

$(\text { Stiller: } 340)^{8}$

Podobne kwestie podniosła tłumaczka Fredzi Phi-Phi. Trzeba bowiem przyznać, że dokładnie zbadała ona przekłady Tuwim - zdaje się, iż jako pierwsza w Polsce - i swoje uwagi zaprezentowała kilkakrotnie, po raz pierwszy kilka lat przed opublikowaniem Fredzi Phi-Phi (zob. Adamczyk, 1982, 1986; Adamczyk-Garbowska; „Albo Fredzia...”: 6). Dostrzegła ona zarówno wady, jak i zalety tekstów Tuwim. Zauważyła, że jej poprzedniczce rzadko zdarzały się pomyłki czy złe zrozumienie angielskich wyrazów i sformułowań. Chwaliła wierne oddanie specyfiki stylu partii prozatorskich, ich prostoty i celowej nieporadności. Doceniła pomysłowość leksykalną, choć odnotowała, że nie wszystkie deformacje czy gry słowne oryginału zostały przetłumaczone. Stwierdziła, że w wielu miejscach zniknęły nonsens i wieloznaczność, co wymusiło usunięcie pewnych fragmentów i dodanie przez Tuwim własnych, ale przyznała też, iż gdzieniegdzie zostały one zachowane. Uznała, że w tłumaczeniach Tuwim jest zbyt wiele zdrobnień, co skutkuje infantylizacją tekstu. Znikęła również dwuadresowość tekstu. Partie poetyckie Adamczyk-Grabowska uznała za zbyt dobre - utwory Pooh są specjalnie nieporadne, w wersji Tuwim zaś twórczość Puchatka okazuje się o wiele bardziej udana. Tłumaczka stwierdziła, że styl Winnie-the-Pooh oraz The House at Pooh Corner jest dziecięcy (prosty), ale nie dziecinny (infantylny), a taki właśnie staje się w Kubusiu Puchatku i Chatce

8 Z najnowszych wypowiedzi biorących w obronę wersje Adamczyk-Garbowskiej szczególnie wyrazista jest praca Jolanty Kozak, stwierdza ona bowiem na przykład: „[...] sygnatura A.A. Milne’a na okładce jest ze strony tłumaczki [Tuwim - dop. A.Ch.] sporym nadużyciem. Uczciwym postawieniem sprawy byłoby rozwiązanie: Irena Tuwim, Kubuś Puchatek, według A.A. Milne'a” czy „Parodia Tuwim - bo tak trzeba nazwać to "tłumaczenie« - całkowicie zmienia charakterystykę głównej postaci” (Kozak: 34, 176). 
Puchatka. Przyznała, że jest to trudne do oddania, gdyż w polskiej literaturze panują inne konwencje, lecz nie uznała tego za niemożliwe.

Adamczyk-Garbowska we wprowadzeniu do Fredzi Phi-Phi zaznaczyła, że podjęła się nowego tłumaczenia, gdyż chciała spróbować przedstawić polskim odbiorcom tekst możliwie wierny oryginałowi (zob. Adamczyk, 1986: 6-7) ${ }^{9}$. W innym miejscu tłumaczka wyjaśniała także, iż zdecydowała się na to, ponieważ kierowało nią „[p]rzekonanie, że w przypadku dzieł wielowymiarowych i klasycznych powinno istnieć jak najwięcej przekładów, gdyż żadna wersja nie jest idealna. Dopiero kilka interpretacji jest w stanie dać pełny obraz oryginału” („Albo Fredzia...”: 6).

Do tego „pełnego obrazu oryginału” przyczyniają się w jakimś stopniu dwa kolejne przekłady Winnie-the-Pooh, czyli prace Agnieszki Traut i Bohdana Drozdowskiego, które ukazały się w krótkim odstępie czasu. Nietypowe to jednak „dopowiedzenia”, gdyż już same tytuły - odpowiednio: O Kubusiu Puchatku oraz Kubuś Puchatek - wyraźnie odnoszą się do tekstów Tuwim, potwierdzając kanoniczność jej propozycji. Drozdowski w reakcji na słowa krytyków, po co podejmować się nowego przekładu, skoro istnieje już tłumaczenie dobrze znane i kochane przez czytelników, wyjaśniał, że po porównaniu wersji Tuwim z oryginałem odkrył, iż „słabo znała [ona - dop. A.Ch.] język zarówno ten, z którego, jak i ten, na który tłumaczyła arcydzieła Milne’a”. Stwierdził też, że tekst Tuwim pełen jest „[...] idiotyzmów, gaf, niedoczytań, nierozumień zastępowanych własnymi pomysłami”, brak w nim „subtelności oryginału”, pojawiają się też „niezliczone kiksy czysto stylistyczne” (Drozdowski: 6-7) ${ }^{10}$. Zdaje się więc choć tłumacz nie mówi o tym wprost - że na różnych poziomach sięga on po rozwiązania Tuwim, ponieważ jego celem jest nie tyle przygotowanie nowej wersji, co usunięcie błędów z przekładu kanonicznego. Trudno jednak wskazać, jaki zamysł przyświecał Traut - nie dysponujemy jakąkolwiek wypowiedzią

9 Znamienne, że Adamczyk-Garbowska chciała, by Fredzia Phi-Phi spełniła oczekiwania dorosłych czytelników, a tak się nie stało. Najpewniej dlatego, iż - jak pisze Jerzy Brzozowski - nie uwzględniła ona „horyzontu oczekiwań czytelników” oraz tradycji przekładowej (Brzozowski: 58).

10 Zarzut, że Tuwim słabo znała język polski, wydaje się wątpliwy na tle zachwytów na stylem Kubusia Puchatka. 
tłumaczki na ten temat ${ }^{11}$. Bardzo prawdopodobne jest, że kryły się za tym względy ekonomiczne i polityka wydawnictw. Niejednokrotnie zamówienie nowego przekładu okazywało się bardziej opłacalne niż wykupienie praw do poprzedniego - rozwiązanie to mogło też być wygodniejsze w latach 90., a więc w czasie zmieniającej się sytuacji politycznej, społecznej i gospodarczej.

Obu tym książkom przyjrzała się Joanna Kokot w artykule poświęconym polskim przekładom opowiadań A.A. Milne’a dla dzieci. Pracę Traut badaczka nazwała uproszczonym wariantem Winnie-the-Pooh i Kubusia Puchatka Tuwim - z tekstu zniknęły gry słowne, niektóre fragmenty zostały pominięte, inne zbyt dosłownie przetłumaczone. Pojawiło się tu wiele błędów ortograficznych, gramatycznych i interpunkcyjnych. Wszystko to sprawiło, że całość jest niespójna. O wersji Drozdowskiego Kokot mówi zaś, że jest to niejako ten sam świat przedstawiony, co u Tuwim, ale inaczej opowiedziany. Kubuś Puchatek z 1938 roku został w pewien sposób włączony w książkę z 1994 roku. Tłumacz uzupełnił to, co zostało pominięte w pierwszym z przekładów, poprawił też błędy, ale i sam sporo dopisał do dzieła Milne’a (zob. Kokot: 372-376) ${ }^{12}$.

$\mathrm{Na}$ przestrzeni lat polskie przekłady Winnie-the-Pooh oraz The House at Pooh Corner stały się przedmiotem wielu badań, choć zdecydowana większość translatologów skupiła się na pracach Tuwim i Adamczyk-Garbowskiej ${ }^{13}$. Z kolei te dwa przekłady, przeciwstawiane sobie, stały się częstym, niemal sztandarowym przykładem dla zobrazowania koncepcji serii translatorskiej, seryjności literatury dziecięcej, przekładu kanonicznego (centralnego) i polemicznego, problemu adaptacji i wiernego przekładu (oraz wielu pojęć mieszczących się między tymi skrajnościami), tłumaczenia nazw własnych, a także kwestii zakorzenienia (udo-

\footnotetext{
11 Nic nie wiadomo też o samej Traut. W kilku katalogach bibliotecznych widnieje ona jako tłumaczka książki Stary cztowiek $i$ morze Ernesta Hemingwaya (wydanej w 1993 r. przez Krajową Agencję Wydawniczą w serii Lektury Ucznia, a więc w tym samym czasie, w tej samej instytucji i w tej samej serii, co O Kubusiu Puchatku).

${ }_{12} \mathrm{~W}$ wydaniu wersji Drozdowskiego zostaje nawet odnotowane na stronie redakcyjnej, że niektóre z nazw własnych oraz jeden z wierszy należą do Tuwim (zob. Milne, 1994: 8).

$13 \mathrm{O}$ pozostałych tekstach, poza wspomnianym i najbardziej wyczerpującym artykułem Kokot, można przeczytać w referacie Justyny Winiarskiej, a o Kubusiu Puchatku Drozdowskiego wspomina także Izabela Szymańska (zob. Winiarska; Szymańska, 2014: 201). Inni badacze nie zajmują się pracami Traut i Drozdowskiego zapewne dlatego, że są one nieosiągalne. Książki można znaleźć w niewielu bibliotekach. Możliwe, iż zostały one wycofane z obiegu na drodze prawnej z uwagi na zbyt daleko idące podobieństwa do przekładu Tuwim.
} 
mowienia) tłumaczenia czy teorii polisystemu (zob. Kokot; Rajewska; Lipiński; Kozak; Woźniak, 2009, 2012; Spyrka; Szymańska, 2014).

Cytowany już Herbert zauważył także: „Obok dwu książek o Kubusiu Puchatku [...] Milne napisał wiele wierszy dla dzieci oraz dwa większe utwory, warte chyba przetłumaczenia - When We Were Very Young [...] i Now We Are Six [...]” (Herbert, 1956: 203) ${ }^{14}$. Jeszcze w tym samym roku, 1956, w „Przekroju” ukazały się trzy wiersze w przekładzie Ireny Tuwim oraz jeden w przekładzie Antoniego Marianowicza (zob. „3 wiersze...”), rok później wydano książkę z wyborem wierszy. Dotychczas w Polsce opublikowano dwa przekłady będące wyborem i dwa pełne przekłady:

\begin{tabular}{|c|c|}
\hline When We Were Very Young (1924) & Now We Are Six (1927) \\
\hline $\begin{array}{c}\text { Wiersze dla Krzysia (1957), wolny przekład: Irena Tuwim i Antoni Marianowicz } \\
\text { (wybór) }\end{array}$ \\
\hline $\begin{array}{c}\text { Niepostuszna mama i inne wierszyki } \\
\text { dla dzieci (1983), wolny przekład: } \\
\text { Stanisław Barańczak (wybór) }\end{array}$ \\
\hline $\begin{array}{c}\text { Kiedy byliśmy bardzo mtodzi (1997), } \\
\text { przeł. Zofia Kierszys }\end{array}$ \\
\hline $\begin{array}{c}\text { Kiedy byliśmy bardzo mtodzi (2005), } \\
\text { przeł. Michał Rusinek }\end{array}$ \\
\hline
\end{tabular}

Tłumaczenie Ireny Tuwim i Antoniego Marianowicza pojawiło się najpewniej na fali polskiej fascynacji Puchatkiem. Stanisław Barańczak pierwsze poezje przełożył na potrzeby artykułu z 1975 roku, w którym przyglądał się problemowi tłumaczenia poezji dla dzieci (zob. Barańczak: 72-74), kilka kolejnych opublikował w tym samym roku na łamach „Przekroju” (zob. „Do dzieci!...”). Wszystkie te utwory, obok kilku innych, weszły do tomu Niepostuszna mama i inne wierszyki dla dzieci ${ }^{15}$. Przekłady Zofii Kierszys to pierwsze pełne wydania

\footnotetext{
14 „[...] wiele wierszy dla dzieci oraz dwa większe utwory, warte chyba przetłumaczenia” - to pomyłka Herberta, ponieważ te dwa większe utwory to właśnie zbiory wierszy.

15 Co ciekawe, książka ta ukazała się nakładem Wydawnictwa Nasza Księgarnia, które w tym samym roku opublikowało też drugie wydanie Wierszy dla Krzysia.
} 
obu zbiorów, próbę tę powtórzył kilka lat później Michał Rusinek ${ }^{16}$. W pierwszym przypadku nie sposób odtworzyć, czy pomysł opublikowania w całości polskich wersji poezji Milne’a należy przypisać tłumaczce czy oficynie, ale jest to możliwe w drugim wypadku. Opowiadał o tym bowiem sam Rusinek:

[...] to był przypadek. Trzynaście lat temu redaktor naczelny Znaku Jerzy Illg przyszedł do Wisławy Szymborskiej z propozycją, by przełożyła wybór wierszyków Milne’a. Odmówiła, twierdząc, że nie zna angielskiego i nigdy nie pisała dla dzieci. Wtedy on westchnąt, rozejrzał się po pokoju, w którym poza nimi byłem tylko ja i spytał „No to może ty?”.

(„Michał Rusinek...”)

Mimo że oba tomiki doczekały się kilku tłumaczeń, wiersze A.A. Milne’a nie są popularne w Polsce. Co prawda, kilka poezji weszło do zbioru antologii opracowanej przez Ryszarda Waksmunda (zob. Poezja dla dzieci...: 104, 150, 245-246, 407-408), utwory w wersji Barańczaka stały się w 1996 roku podstawą do spektaklu Teatru Telewizji (Niepostuszna mama. FilmPolski. pl), a w 2012 roku wiersz Śniadanie króla w przekładzie Marianowicza doczekał się osobnej publikacji - ukazał się on w serii „Mistrzowie Ilustracji” w Wydawnictwie Dwie Siostry w opracowaniu graficznym Eryka Lipińskiego. Zdaje się jednak, że wiersze funkcjonują w polskiej recepcji przede wszystkim jako mniej znane książki autora znanego Kubusia Puchatka ${ }^{17}$. Trudno o recenzje krytyków, a także o badania translatologów. W latach 50. Wiersze dla Krzysia recenzowała Krystyna Kuliczkowska i - co znamienne - czytała je niejako przez pryzmat opowiadań: „Z rzadka wprawdzie występuje tu sam Puchatek, ale przecież wierszyk Cesarza [...] jest odmianą puchatkowej »mruczanki« [...]” (Kuliczkowska: 1309). Kilka kolejnych, skromnych wypowiedzi pojawiło się dopiero parę lat temu, po wznowieniu tłumaczenia Michała Rusinka. Z badaczy zaś poezjami zajął się jedynie pokrótce Barańczak we wspomnianym już tekście.

\footnotetext{
16 Rusinek to kolejna osoba, która wymienia opowiadania i wiersze w wersji Tuwim jako jedną z ważniejszych lektur dzieciństwa, przy okazji mówi też o swojej pracy translatorskiej (zob. „Co czytali...”: 220).

17 Nagłówek z „Przekroju” reklamujący kilka wierszy brzmi: „Do DzIEcı! Po zjedzeniu strony poprzedniej (ciastka!), przeczytajcie te WIERSze, które napisał dla Was ta ta Kubusia Pu chatka Alan A. Milne, a przetłumaczył Stanisław Barańczak” („Do dzieci...”: 28 [podkr. - A.Ch.]).
} 
Kubuś Puchatek Ireny Tuwiem niezwykle trwale zapisał się w świadomości i w sercach polskich odbiorców - w tym także w świadomości i sercach najznakomistszych polskich badaczy i twórców. Jak się zdaje, nastąpiło to bardzo szybko - przytoczone wyżej świadectwa pochodzą przede wszystkim z lat 40 . i 50., a więc ledwie z dziesięciu czy piętnastu lat. I choć w kolejnych dziesięcioleciach trudno o podobne wypowiedzi, to niezwykła dyskusja, jaka rozgorzała wokół polemicznego przekładu Moniki Adamczyk-Garbowskiej na przełomie lat 80. i 90. potwierdza, że propozycja Ireny Tuwim stała się pozycją kanoniczną, klasyczną, wręcz monumentalną. "Zasłoniła” ona bowiem, uczyniła obcymi, oryginał i jego autora $^{18}$ - to Kubus Puchatek, nie Winnie-the-Pooh, stanowi dla krytyków i czytelników punkt odniesienia. „Przykryła” też poezje A.A. Milne’a dla dzieci - wiersze, pomimo kilku przekładów, nie cieszą się zbytnim zainteresowaniem odbiorów (w tym badaczy). Pozycja Kubusia Puchatka, adaptacji silnie udomowionej, okazuje się na tyle pewna, że opiera się współczesnym trendom przekładowym. W książkach dla dzieci coraz częściej mówić możemy o egzotyzacji; tłumacze i wydawcy pokładają obecnie większą ufność w zdolności perecepcyjne młodych czytelników, wydawać by się więc mogło, że albo Fredzia Phi-Phi będzie cieszyć się większym zainteresowaniem, albo przygotowany zostanie nowy przekład, jednak - jak do tej pory - tak się nie dzieje.

\section{Bibliografia}

„3 wiersze A.A. Milne’a”. Przekrój 582 (1956): 9.

Adamczyk, Monika. „Czy Kubuś Puchatek to Winnie-the-Pooh? O potrzebie krytyki przekładu". Akcent 4 (1982): 73-85.

-----. „Od tłumacza”. Alan Alexander Milne. Fredzia Phi-Phi. Tłum. Monika Adamczyk. Lublin: Wydawnictwo Lubelskie. 5-7.

${ }^{18}$ Do „nieobecności” autora w świadomości polskich czytelników przyczyniają się także zapewne dwa inne czynniki: po pierwsze fakt, że mówimy o książce, z którą zazwyczaj zapoznajemy się jako dzieci, a w ich świadomości zapisuje się raczej historia niż jej autor; po drugie niebagatelny jest też wpływ animacji Disneya, które również w pewien sposób zawłaszczają adaptowane dzieła, odsuwając na bok twórców. 
Adamczyk-Garbowska, Monika. Polskie ttumaczenia angielskiej literatury dziecięcej. Problemy krytyki przektadu. Wrocław: Zakład Narodowy im. Ossolińskich, 1988.

„Albo Fredzia Phi-Phi, albo Kubuś Puchatek. Z Moniką Adamczyk-Garbowską, tłumaczką, rozmawia Piotr Wasilewski”. Tak i Nie 9 (1988): 6.

Augustyniak, Anna. Irena Tuwim. Nie umartam z mitości. Warszawa: Trzecia Strona, 2016.

Barańczak, Stanisław. „Rice pudding i kaszka manna. O tłumaczeniu poezji dla dzieci”. Tegoż. Ocalone w ttumaczeniu. Szkice o warsztacie ttumacza poezji z dodatkiem matej antologii przektadów-problemów. Wyd. 3 popr. i rozszerz. Kraków: Wydawnictwo a5, 2004. 65-75.

Bibliografia prac Ireny Tuwim. Oprac. Tadeusz Januszewski. http://tuwim.org/index. php?s=19 [dostęp: 15.03.2020].

Brzozowski, Jerzy. „Strategie przekładu”. Tegoż. Stanać po stronie ttumacza. Zarys poetyki opisowej przektadu. Kraków: Wydawnictwo Uniwersytetu Jagiellońskiego, 2011. 47-64.

Carpenter, Humphrey. „A.A. Milne and Winnie-the-Pooh. Farewell to the Enchanted Places". Humphrey Carpenter. Secret Gardens. A Study of the Golden Age of Children's Literature. London-Sydney: Unwin Paperbacks, 1987. 188-209.

Co czytali sobie, kiedy byli mali?. Rozmawiali Ewa Świerżewska, Jarosław Mikołajewski. Warszawa: Egmont Polska - Agora, 2014.

„Do dzieci! Wiersze A.A. Milne’a”. Przekrój 51 [numer specjalny] (1975): 28.

Drozdowski, Bohdan. „Kubuś Puchatek i S-ka”. Wiadomości Kulturalne 47 (1997): 6-7.

Franaszek, Andrzej. „Kubus’”. Tegoż. Herbert. Biografia. T. 1. Niepokój. Kraków: Znak, 2018. 591-610.

Gralewicz-Wolny, Iwona. „Od Winifredy do Jakuba, czyli Puchatek była kobietą?”. Par cœur. Twórczość dla dzieci i mtodzieży raz jeszcze. Red. Iwona Gralewicz-Wolny, Beata Mytych-Forajter. Katowice: Wydawnictwo Uniwersytetu Śląskiego, 2016. 227-240.

Haring-Smith, Tori. A.A. Milne. A Critical Bibliography. New York-London: Garland Publishing, 1982.

Herbert, Zbigniew. „A.A. Milne”. Twórczość 4 (1956): 202-204.

----. „Niedźwiedzie”. Tegoż. Hermes, pies i gwiazda. Warszawa: Wydawnictwo Czytelnik, 1957. 136. 
Jarniewicz, Jerzy. „Jak Kubuś Puchatek stracił dziecięctwo”. Tegoż. Gościnność stowa. Szkice o przektadzie literackim. Kraków: Znak, 2012. 225-231.

Kokot, Joanna. „O polskich tłumaczeniach Winnie-the-Pooh A.A. Milne’”. Przektadajac nieprzektadalne. Materiaty z I Międzynarodowej Konferencji Translatorycznej Gdańsk-Elblag. Red. Wojciech Kubiński, Ola Kubińska, Tadeusz Z. Wolański. Gdańsk: Wydawnictwo Uniwersytetu Gdańskiego, 2000. 365-378.

Kozak, Jolanta. Przektad literacki jako metafora. Między logos a lexis. Warszawa: Wydawnictwo Naukowe PWN, 2009.

Kuliczkowska, Krystyna. „Pośmiertny prezes klubu Pickwicka”. Nowe Książki 21 (1957): 1309.

Lem, Stanisław. „Lektury dzieciństwa”. Dekada Literacka 11-12 (1992): 11, 14.

Lipiński, Krzysztof. „Mit brzydkiego kaczątka / gorszości. Czy przekład może być lepszy od oryginału?”. Tegoż. Mity przektadoznawstwa. Kraków: Wydawnictwo EGIS, 2004. 60-77.

Melrose, A.R. Puchatkowa czytanka-przedspanka, w której A.R. Melrose z upodobaniem wielkim i radością zgromadzit Ciekawe Anegdotki, Tajemnicze Karteczki, Co Nieco Wspomnień oraz Mnóstwo Wiadomości (i Dtugich Stów) o ukochanych bohaterach książek A.A. Milne’a i Ernesta H. Sheparda. Tłum. Ewelina Jagła. Poznań: Dom Wydawniczy Rebis, 1997.

„Michał Rusinek: Disney skrzywdził Kubusia Puchatka. Nowa książka o przygodach najsłynniejszego misia na świecie”. Rozmowa Emilii Dłużewskiej z Michałem Rusinkiem. Wyborcza.pl. 13 kwietnia (2017). http://wyborcza.pl/7,75517,21634639,michal-rusinek-disney-skrzywdzil-kubusia-puchatka-nowa-ksiazka.html [dostęp: 15.03.2020].

Milne, Alan Alexander. By Way of Introduction. London: Methuen \& Co., 1929.

Kubuś Puchatek. Tłum. Bohdan Drozdowski. Warszawa: Wydawnictwo Philip Wilson, 1994.

Miłosz, Czesław. „Krzyś”. Tegoż. Piesek przydrożny. Kraków: Znak, 2016. 226.

Niepostuszna mama. FilmPolski.pl. Internetowa baza filmu polskiego. http://www. filmpolski.pl/fp/index.php?film=521093 [dostęp: 15.03.2020].

Niepostuszna mama. Polska Bibliografia Literacka [Spektakle fabularne TV]. http:// pbl.ibl.poznan.pl/dostep/index.php?s=d_biezacy\&f=zapisy\&p_tytul=niepos\%C5\%82uszna+mama\&submit.x=0\&submit.y=0 [dostęp: 15.03.2020].

Nowak, Andrzej. „Fredzia, której nie było, czyli Penelopa w pułapce”. Dekada Literacka 3 (1992): 12. 
Poezja dla dzieci. Antologia form i tematów. Oprac. Ryszard Waksmund. Wrocław: Wydawnictwo Uniwersytetu Wrocławskiego, 1987.

Rajewska, Ewa. „»Zakorzenienie“ przekładu a polskie tłumaczenia Winnie-the-Pooh Alexandra Alana Milne'a”. Przektad w historii literatury. Red. Piotr Fast, Katarzyna Żemła. Katowice: Wydawnictwo Naukowe „Śląsk”, 2002. 59-71.

Rogoż, Michał. „Kubuś Puchatek jako bohater wielu pokoleń. Z dziejów recepcji arcydzieła Alana Aleksandra Milne’a na polskim rynku wydawniczym”. Mtody odbiorca w kręgu lektur pożytecznych i szkodliwych. Red. Krystyna Heska-Kwaśniewicz przy współpracy Sylwii Gajownik. Katowice: Wydawnictwo Uniwersytetu Śląskiego, 2012.

Spyrka, Lucyna. „Przekład udomowiony - przekład wyobcowany”. Przekłady Literatur Stowiańskich 2 (2011): 251-265.

Staniuk, Jolanta. „Przekład zakorzeniony jako przejaw manipulizmu na podstawie odbioru Kubusia Puchatka i Fredzi Phi-Phi". Między oryginatem a przektadem 1 (2019): 85-95.

Stiller, Robert. „Powrót do Carrolla”. Literatura na Świecie 5 (1973): 330-363.

Szymańska, Izabela. „Przekłady polemiczne w literaturze dziecięcej”. Rocznik Przekładoznawczy. Studia nad teoria, praktyka i dydaktyka przektadu 9 (2014): 193-208.

------. „Serie translatorskie w polskich przekładach anglojęzycznej literatury dziecięcej. Obraz adresata jako motyw łączący serię". 50 lat polskiej translatoryki. Red. Krzysztof Hejwowski, Anna Szczęsny, Urszula Topczewska. Warszawa: Uniwersytet Warszawski, 2009. 513-527.

Thwaite, Ann. A.A. Milne. Jego życie. Tłum. Małgorzata Glasenapp. Warszawa: Wydawnictwo W.A.B., 2009.

Tuwim, Irena. „Sprawa adaptacji”. Nowa Kultura 26 (1952): 10.

Winiarska, Justyna. „Fredzia Phi-Phi czy Kubuś Puchatek?”. Jezzyk Polski 5 (2001): 334-338.

Woźniak, Monika. „Czym jest "poprawność polityczna" w przekładach literatury dziecięcej”. 50 lat polskiej translatoryki. Red. Krzysztof Hejwowski, Anna Szczęsny, Urszula Topczewska, Warszawa: Uniwersytet Warszawski, 2009. 505-512.

-----. „Puchata przepustka do sławy. Pochwała Ireny Tuwim”. Przektadaniec 26 (2012): $115-134$.

Woźniakowski, Krzysztof. „Książka dla dzieci w ofercie wydawniczej środowiska polskich uchodźców na Węgrzech okresu II wojny światowej”. Annales Universitatis 
Pasedagogicae Cracoviensis. Studia et Bibliothecarum Scientiam Pertinentia 12 (2014): 69-85.

Wullschläger, Jackie. „A.A. Milne. The Fantasy Tamed”. Tejże. Inventing Wonderland. The Lives and Fantasies of Lewis Carroll, Edward Lear, J.M. Barrie, Kenneth Grahame and A.A. Milne. London: Methuen, 1995. 175-199.

Wyka, Kazimierz. „Pan Pickwick na łyżwach [„Odrodzenie” 1948, nr 3]”. Stanisław Frycie. Literatura dla dzieci i mtodzieży $w$ latach 1945-1970. T. 2. Wyd. 2. Warszawa: Wydawnictwa Szkolne i Pedagogiczne, 1982. 506-509.

\section{Winnie-the-Pooh as the other to Polish Literature}

\section{Summary}

A.A. Milne is known primarily as an author of four books for children - two volumes of poetry, When We Were Very Young (1924) and Now We Are Six (1927), and also two collections of stories, Winnie-the-Pooh (1926) and The House at Pooh Corner (1928). These books have been extremely successful all over the world, but in Poland the most popular have been the collections of stories about the adventures of the teddy bear and his friends. The translations by Irena Tuwim - Kubus Puchatek and Chatka Puchatka (both 1938) - have become beloved books for many readers. Shortly after the Second World War and in the next decades the words spoken by Miś o Małym Rozumku [the Bear of a Very Little Brain] and by other animals from the Forest came into use in Polish. Irena Tuwim's transalation very fast became canonical, but at the same time Winnie-thePooh became unknown. This article is devoted to the Polish reception of A.A. Milne's work for children. It examines why Kubus' Puchatek became so popular in the post-war years, but also how this success have influenced the reception of subsequent translations.

Keywords: children's literature, Alan Alexander Milne, Winnie-the-Pooh, Kubus' Puchatek, Irena Tuwim, reception, translation

Słowa kluczowe: literatura dla dzieci, Alan Alexander Milne, Winnie-the-Pooh, Kubuś Puchatek, Irena Tuwim, recepcja, przekład 